\title{
TRANSLATING THE COMBINATION OF GENE THERAPY AND TISSUE ENGINEERING FOR TREATING RECESSIVE DYSTROPHIC EPIDERMOLYSIS BULLOSA
}

\author{
A. Dakiw Piaceski $i^{1,2,4}$, D. Larouche $e^{1,2,4}$, K. Ghani ${ }^{3,4}$, F. Bisson ${ }^{1,2,4}$, S. Cortez Ghio ${ }^{1,2,4}$, S. Larochelle L $^{1,2,4}$, \\ V. J. Moulin ${ }^{1,2,4}$, M. Caruso ${ }^{3,4, \$, *}$ and L. Germain ${ }^{1,2,4, \S}$ \\ ${ }^{1}$ Université Laval Research Center on Experimental Organogenesis/LOEX, Quebec City, \\ Quebec, G1J 1Z4, Canada, Quebec City, \\ Quebec, G1V 0A6, Canada \\ ${ }^{2}$ Department of Surgery, Faculty of Medicine, Université Laval, Quebec City, \\ Quebec, G1V 0A6, Canada \\ ${ }^{3}$ Department of Molecular Biology, Medical Biochemistry and Pathology, Cancer Research Institute, \\ Université Laval, Quebec City, Quebec, G1R 3S3, Canada \\ ${ }^{4} \mathrm{CHU}$ de Québec - Université Laval Research Centre, Quebec City, Quebec, G1R 3S3, Canada \\ $\S$ These authors contributed equally
}

\begin{abstract}
The combination of gene therapy and tissue engineering is one of the most promising strategies for the treatment of recessive dystrophic epidermolysis bullosa (RDEB). RDEB is a rare genetic disease characterised by mutations in the COL7A1 gene, encoding type VII collagen (COLVII), which forms anchoring fibrils at the dermal-epidermal junction of the skin. This disease causes severe blistering and only palliative treatments are offered. In this study, the base of a strategy combining gene therapy and a tissue-engineered skin substitute (TES), which would be suitable for the permanent closure of skin wounds, was set-up. As a high transduction efficiency into fibroblasts and/or keratinocytes seems to be a prerequisite for a robust and sustained correction of RDEB, different envelope pseudotyped retroviral vectors and the transduction enhancer EF-C were tested. When green fluorescent protein (GFP) was used as a reporter gene to evaluate the retroviral-mediated gene transfer, the fibroblast infection efficiency was $30 \%$ higher with the Ampho pseudotyped vector as compared with the other pseudotypes. At least a 3.1-fold and a 1.3-fold increased transduction were obtained in fibroblasts and keratinocytes, respectively, with EF-C as compared with polybrene. A continuous and intense deposit of haemagglutinin (HA)-COLVII was observed at the dermal-epidermal junction of self-assembled TESs made of cells transduced with a HA-tagged COL7A1 vector. Furthermore, HA-tagged basal epidermal cells expressing keratin 19 were observed in TESs, suggesting stem cell transduction. This approach could be a valuable therapeutic option to further develop, in order to improve the long-term life quality of RDEB patients.
\end{abstract}

Keywords: Acantholysis bullosa, epidermolysis bullosa dystrophica, cell- and tissue-based therapy, tissue engineering, cell culture techniques, genetic therapy, collagen type VII.

*Address for correspondence: Manuel Caruso, Cancer Research Centre, Université Laval, Quebec City, Quebec, G1R 3S3, Canada.

Telephone: +418 $4185254444 \quad$ Email: Manuel.Caruso@crchudequebec.ulaval.ca

\section{Introduction}

Epidermolysis bullosa (EB) is a genetic disease comprising a heterogeneous group of rare inherited skin disorders in which minor mechanical stress to the skin and mucous membranes causes the formation of blisters and erosions. There are four major types of $\mathrm{EB}$, characterised by the location of the defective proteins and the level of blisters: EB simplex (EBS; epidermolytic), junctional EB (JEB; lucidolytic), dystrophic EB (DEB; dermolytic) and Kindler syndrome (mixed levels of blistering) (Aumailley et al., 2006; Fine et al., 2014). In the skin of patients with DEB, blister formation occurs beneath the lamina densa within the papillary dermis. Mutations in the COL7A1 gene are responsible for DEB, which can be autosomal dominant or recessive (RDEB), depending on the type of mutations (Kern et al., 2009). The COL7A1 gene encodes type VII collagen (COLVII), which is naturally secreted into the extracellular space by dermal fibroblasts and epidermal keratinocytes (Bruckner-Tuderman et al., 1999). These collagen molecules assemble into anchoring fibrils, a major component of the dermal-epidermal junction (DEJ), 
responsible for the adhesion between the epidermis and the dermis (Bruckner-Tuderman et al., 1999). DEB is characterised by abnormalities in anchoring fibrils, which are absent, reduced in number or malformed. Patients with RDEB can display other symptoms than blistering and fragility of the skin and mucous membranes; their hands and feet can be deformed and they can suffer from anaemia, malnutrition and growth retardation. The development of squamous cell carcinoma in areas subjected to intense blistering is a common trait in RDEB patients over the age of 30. There is no cure for RDEB and only palliative treatments restricted to individual wounds are currently offered to patients (Aumailley et al., 2006; Rashidghamat and McGrath, 2017; Uitto et al., 2016).

Several experimental strategies for RDEB have been tested in preclinical studies and in patients. These comprise protein therapy, cell therapy (fibroblasts, mesenchymal stromal cells and haematopoietic stem cells), antisense oligonucleotidemediated exon skipping and gene therapy, including genome engineering (Rashidghamat and McGrath, 2017). The latter approach was also used by Bauer et al. (2016) and Mavilio et al. (2006) to successfully treat two JEB patients. They cultured keratinocytes, obtained from the patients' own skin, in vitro and transduced them with a retroviral vector containing the $L A M B 3$ gene, which encodes a subunit of laminin 332, another component of the DEJ. After expansion of the corrected cells, they successfully transplanted cultured epidermal sheets onto small areas containing wounds. Very recently, the same team was able to successfully graft $80 \%$ of the body surface of a JEB patient with a transgenic epidermis, a procedure that was life-saving (Hirsch et al., 2017). The transgene was expressed during the 21-month follow-up and the epidermis was fully functional and did not form blisters. This proof of principle suggests that this strategy could be applied to other EB types (De Rosa et al., 2014; Hirsch et al., 2017; Mavilio et al., 2006).

Compared to the LAMB3 cDNA (3.6 kb) (Mavilio et al., 2006), the large size of the COL7A1 cDNA $(8.9 \mathrm{~kb})$ has limited the generation of high-titer retroviral vectors from stable retrovirus-producer cells (Chen et al., 2002; Goto et al., 2006; Siprashvili et al., 2010). The use of high-titer retroviral packaging cell lines (293Vec cells), constructed in our laboratory, could circumvent the titer issue. They release viral particles pseudotyped with the amphotropic (Ampho), the baboon endogenous virus (Baev), the gibbon ape leukaemia virus (Galv) and the feline endogenous retrovirus (RD114) envelopes (Ghani et al., 2007; Ghani et al., 2009). In the present study, the potential of GFP and COL7A1 vectors, produced from these packaging cell lines, for the transduction of human keratinocytes and fibroblasts was investigated. Also, a 12-amino acid peptide, EF-C, derived from the HIV-1 envelope glycoprotein, was tested. Once assembled in nanofibrils, EF-C is shown to be more potent than the commonly used polycation polybrene for increasing the transduction of fibroblasts and macrophages (Meier et al., 2014; Yolamanova et al., 2013).

A bilayered skin substitute, with both a dermis and an epidermis, could significantly improve the outcome of a graft in RDEB patients in terms of resistance and mechanical properties. Furthermore, if the COL7A1 gene was introduced in fibroblasts as well as in keratinocytes, COLVII production at the DEJ should be optimal. A variety of methods, based on the addition of biomaterials, synthetic materials or exogenous extracellular matrix, are proposed to produce bilayered skin substitutes (Bell et al., 1979; Berthod et al., 1993; Boyce et al., 2006; Sun et al., 2014). A bilayered tissue-engineered skin (TES) was produced by the self-assembly approach, in which the cells produce and organise their own extracellular matrix (Larouche et al., 2016; Michel et al., 1996; Pouliot et al., 2002). Autologous TESs are successfully used to treat ulcers and burn patients (Duranceau, 2014). A clinical trial assessing the efficacy of autologous TESs for the permanent coverage of full-thickness wounds is currently ongoing in Canada (ClinicalTrials.gov; NCT02350205).

In this study, the use of retroviral vectors produced from the $293 \mathrm{Vec}$ packaging cell lines was investigated for their ability to transduce fibroblasts and keratinocytes in presence of the EF-C peptide. The potential of transduced cells for producing and organising COLVII at the DEJ of TESs produced by the self-assembly approach was also assessed for the first time.

\section{Materials and Methods}

\section{Ethics}

The study was approved by the Ethics committee of the CHU de Québec - Université Laval Research Centre, Quebec City, Quebec for the protection of human subjects and conducted in accordance with the Helsinki Declaration of 1975.

\section{Plasmids}

The GFP retroviral plasmid was derived from GFP3 and contained a hygromycin resistance gene (Hygror) followed by an encephalomyocarditis virus internal ribosomal entry site sequence linked to the GFP gene. Both genes were under the control of the Moloney murine leukaemia virus (MoMLV) long terminal repeat (LTR) sequences (Qiao et al., 2002). The pLZRS-HACOL7A1 retroviral plasmid, containing a human influenza haemagglutinin (HA)-tagged fulllength human COL7A1 gene under the control of the MoMLV LTR sequence, was kindly provided by Alfred Lane (Stanford University School of Medicine, Standford, CA, USA) (Siprashvili et al., 2010).

\section{Cell culture}

HT-1080 cells, 293T cells, the retrovirus parental packaging cell lines 293Vec-Ampho, 293Vec-Baev, 
293Vec-Galv, 293Vec-RD114 (Ghani et al., 2007; Ghani et al., 2009) and their derivatives, containing the GFP vector and the $H A-C O L 7 A 1$ vector, were cultured in Dulbecco's modified Eagle's medium (DMEM; Life Technologies, Burlington, ON, Canada) supplemented with $10 \%$ foetal calf serum (Wisent Bioproducts Inc, Saint-Jean-Baptiste, QC, Canada) and $1 \%$ penicillin (Sigma-Aldrich, St Louis, MO, USA)/gentamicin (Galenova, St-Hyacinthe, QC, Canada). The retrovirus-producer cell lines were generated by infection with VSV-G pseudotyped recombinant retroviruses produced by transient transfection of 293T cells. Subsequently, producer cells infected with the GFP virus were selected in $200 \mu \mathrm{g} / \mathrm{mL}$ hygromycine (Calbiochem, Etobicoke, ON, Canada), resulting $99 \%$ GFP positive, as assessed by fluorescence-activated cell sorting (FACS) analysis. The 293Vec-Ampho-HA-COL7A1 cells were assessed by immunofluorescence.

Human fibroblasts (18- and 37-year-old donors) and keratinocytes (26- and 37-year-old donors) were obtained from reductive breast surgery of healthy adult women after informed consent was given. Fibroblasts and keratinocytes were isolated by the two-step thermolysine and trypsin method, as previously described (Germain et al., 1993; Lavoie et al., 2013). Briefly, skin biopsies were digested overnight at $4{ }^{\circ} \mathrm{C}$ in HEPES buffer [10 mM 4-(2-hydroxyethyl)-1-piperazine ethane sulfonic acid (MP Biomedicals Inc., Montreal, QC, Canada), $6.7 \mathrm{mM} \mathrm{KCl}, 142 \mathrm{mM} \mathrm{NaCl}$ and $1 \mathrm{mM}$ $\mathrm{CaCl}_{2}$ ] containing $500 \mathrm{mg} / \mathrm{mL}$ thermolysine (SigmaAldrich). Then, the dermis was separated from the epidermis with the use of forceps. Keratinocytes were dissociated from the epidermis for $15 \mathrm{~min}$ at $37^{\circ} \mathrm{C}$ in a trypsin/ethylene-diaminetetraacetic acid (EDTA) solution [0.05\% trypsin 1 : 500 (Intergen, Toronto, ON, Canada) and $0.01 \%$ EDTA/disodium salt prepared in phosphate-buffered saline (PBS)]. Next, fibroblasts and keratinocytes were collected by centrifugation and plated for primary cell culture (P0) and further passages. Cells were cryopreserved by the slow-rate cooling method, where primary cultures of freshly extracted keratinocytes or fibroblasts are trypsinised, counted and centrifuged. Cell pellets were kept on ice until resuspension at a density of $1 \times 10^{6}$ or $2 \times 10^{6}$ cells $/ \mathrm{mL}$ in a cold $\left(4^{\circ} \mathrm{C}\right)$, freezing medium consisting of $90 \%$ foetal calf serum and $10 \%$ dimethyl sulphoxide (DMSO; Sigma-Aldrich) and, then, distributed in cryogenic vials (Nalgene ${ }^{\circledR}$ Labware, Rochester, NY, USA). Next, cryogenic vials were placed in a freezing container (Nalgene ${ }^{\circledR}$ Labware) filled with $99 \%$ ethanol and precooled at $4{ }^{\circ} \mathrm{C}$ and kept at $-80{ }^{\circ} \mathrm{C}$ for $24 \mathrm{~h}$ to allow a freezing rate of $-1^{\circ} \mathrm{C} / \mathrm{min}$. Cells were stored in liquid nitrogen until use (Germain et al., 1993; Lavoie et al., 2013).

Fibroblasts were thawed at $37^{\circ} \mathrm{C}$ and cultured at passages three to four (P3-4) in DMEM containing $10 \%$ foetal calf serum and antibiotics. Keratinocytes were thawed at $37^{\circ} \mathrm{C}$ and cultured at passage one (P1) in keratinocyte medium [3:1 mixture of the
DMEM and Ham's F12 medium (Life Technologies)], supplemented with $5 \%$ FetalClone II (HyClone ${ }^{\mathrm{TM}}$, Logan, UT, USA), $5 \mu \mathrm{g} / \mathrm{mL}$ insulin (Sigma-Aldrich), $0.4 \mu \mathrm{g} / \mathrm{mL}$ hydrocortisone (Calbiochem), $0.212 \mu \mathrm{g} / \mathrm{mL}$ isoproterenol hydrochloride (Sandoz, Boucherville, QC, Canada), $10 \mathrm{ng} / \mathrm{mL}$ epidermal growth factor (Austral Biologicals, San Ramon, CA, USA), 100 IU/ $\mathrm{mL}$ penicillin $\mathrm{G}$ and $25 \mu \mathrm{g} / \mathrm{mL}$ gentamicin (SigmaAldrich). For all experiments, keratinocytes were co-cultured with irradiated human fibroblast feeder layers (iHFL), as previously described (Bisson et al., 2013). Briefly, iHFL were pre-seeded in flasks at a concentration of 8000 cells $/ \mathrm{cm}^{2}$ at least one week prior to use and kept in culture for a maximum of one month. Keratinocytes in every condition were passaged when they reached $80-90 \%$ confluence (Bisson et al., 2013).

\section{Retroviral infection}

GFP viral titers were determined by scoring positive target cells by FACS analysis. Briefly, HT-1080 cells were inoculated at a density of $1 \times 10^{5}$ cells/well in 24-well plates and cultured overnight in $1 \mathrm{~mL}$ of medium. The medium from each well was replaced with serial dilutions of virus supernatant in $1 \mathrm{~mL}$ final volume containing $8 \mu \mathrm{g} / \mathrm{mL}$ hexadimethrine bromide (polybrene; Sigma-Aldrich). $48 \mathrm{~h}$ later, cells were trypsinised and analysed for GFP fluorescence by FACS. For the HA-COL7 A1 vector, HT-1080 cells were infected in 6-well plates and positive cells for HA were measured by immunofluorescence. Vector titers were calculated as follows: titer $=\mathrm{F} \times \mathrm{Cinf} / \mathrm{V} \times \mathrm{D}$, where $\mathrm{F}$ was the percentage of GFP- or HApositive cells, determined by flow cytometry or immunofluorescence; Cinf the total number of target cells at the time of infection; $\mathrm{V}$ the viral volume applied; D the virus dilution factor. Infections resulting in 2-20\% of GFP- or HA-positive cells were considered for titer calculation based on the linear range of the assay. Titers obtained for the four pseudotyped GFP viruses were $2 \times 10^{7}$ infectious viral particles (ivp) $/ \mathrm{mL}$. The titer for the 293Vec-AmphoHA-COL7A1 was $2 \times 10^{5} \mathrm{ivp} / \mathrm{mL}$.

The infectivity of the four GFP pseudotyped retroviruses in presence of polybrene and EF-C (Genscript, Piscataway Township, NJ, USA) was assessed by infecting normal fibroblasts or keratinocytes plated at a density of $13,000 \mathrm{cells} / \mathrm{cm}^{2}$ in 12-well plates. Fibroblasts were incubated for $2 \mathrm{~h}$ and keratinocytes for $4 \mathrm{~h}$ at $37^{\circ} \mathrm{C}$ in $8 \% \mathrm{CO}_{2}$. Then, fibroblasts were transduced at a multiplicity of infection (MOI) of 0.3 and keratinocytes at MOI of 1 in the presence of $8 \mu \mathrm{g} / \mathrm{mL}$ of polybrene or $10 \mu \mathrm{g} /$ $\mathrm{mL}$ of EF-C. Transduction efficiency was evaluated by FACS analysis. The transduction with the $H A$ COL7A1 vector was performed similarly to the GFP viruses, but in $75 \mathrm{~cm}^{2}$ flask at MOI of 0.36 only for fibroblasts (18-year old donor) and keratinocytes (26-year old donor). The expression of HA-COL7A1 was assessed by immunofluorescence. 


\section{Colony-forming efficiency assay}

For determination of colony-forming efficiency (CFE), $1 \times 10^{2}$ keratinocytes $/ \mathrm{cm}^{2}$ were plated in Petri dishes with iHFL $\left(8 \times 10^{3}\right.$ cells $\left./ \mathrm{cm}^{2}\right)$ and maintained for $9 \mathrm{~d}$ in monolayer cultures (Barrandon and Green, 1987; Lavoie et al., 2013; Rheinwald and Green, 1975). Three Petri dishes per condition were seeded. Then, colonies were fixed in $3.7 \%$ buffered formaldehyde and analysed using a fluorescent imaging scanner (Typhoon TRIO+ Variable Mode Imager; GE Healthcare Life Sciences, Chicago, IL, USA). Using an inverted microscope (Zeiss Axio Observer.A1, Zeiss, Oberkochen, Germany), colonies were classified as holoclones, meroclones and paraclones, according to the size of colonies and the morphology of cells forming them, as described by Barrandon and Green (1987). The percentage of CFE was calculated as follows: number of holoclones, meroclones and paraclones formed divided by the number of seeded cells multiplied by 100 . The percentages of GFPpositive holoclones and meroclones were compared among the different conditions.

\section{Tissue-engineered skin substitutes}

The tissue-engineered skin method used derived from the self-assembled skin substitute method referred

a

EF-C

Polybrene

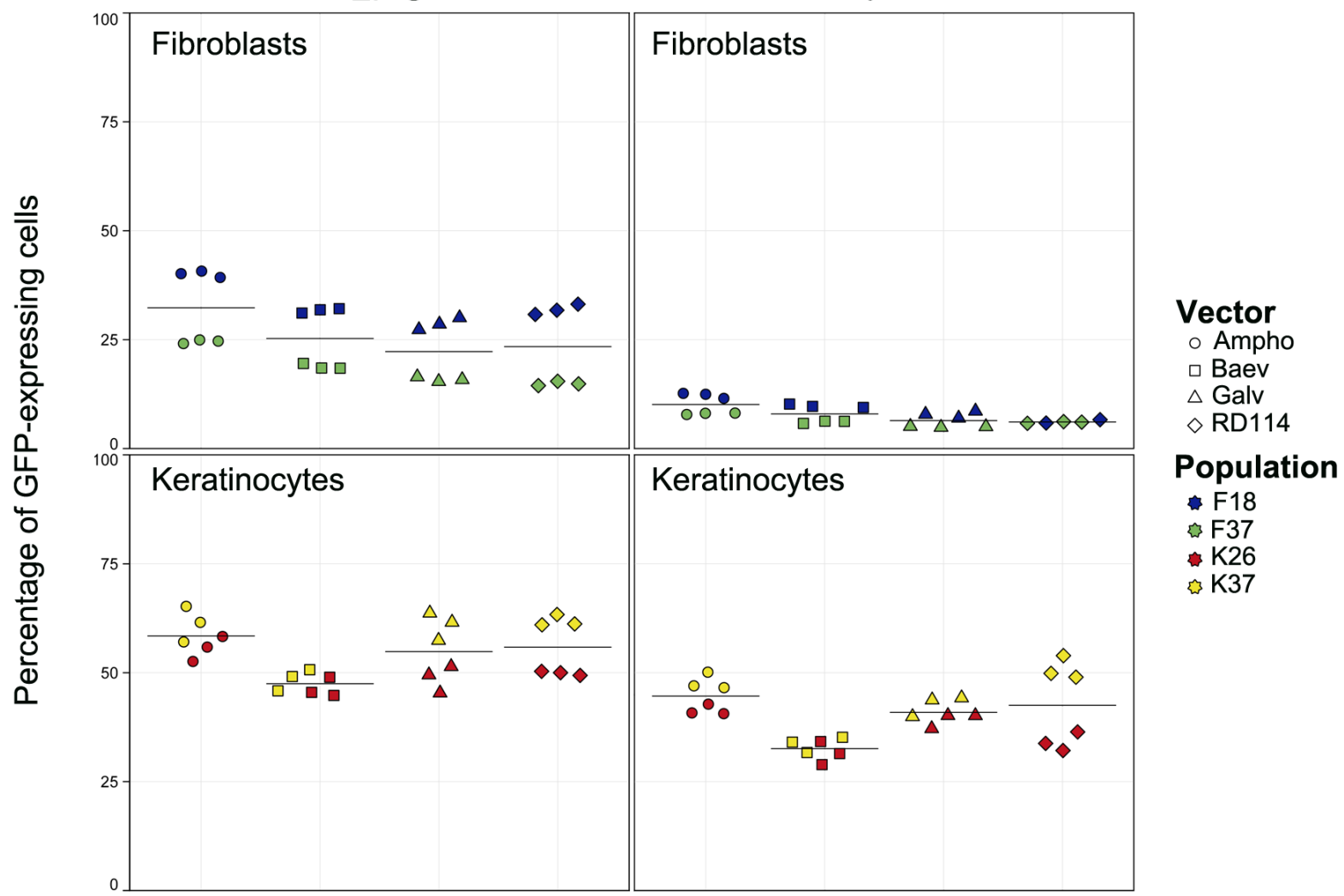

b
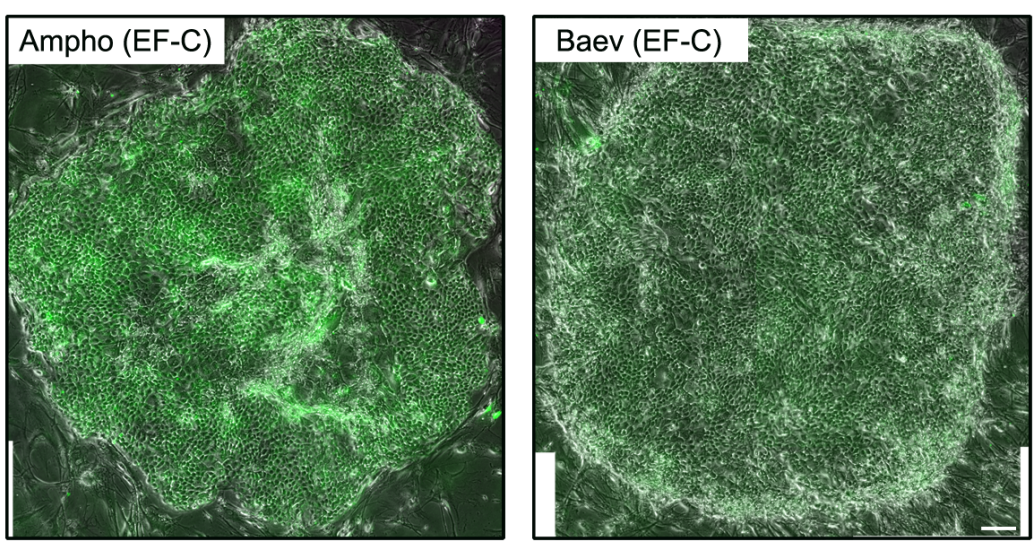

Fig. 1. (a) Analysis of GFP-expressing cells by flow cytometry. Effect of pseudotyped particles Ampho, Baev, Galv and RD114 on transduction of fibroblasts at MOI 0.3 and keratinocytes at MOI 1. Effect of the enhancers polybrene and EF-C peptide on transduction of fibroblasts and keratinocytes. (b) Representative images of GFP-positive holoclones. For the presented colonies, viral particles pseudotyped with Ampho (left panel) and Baev (right panel) were used to transduce cells in presence of the EF-C peptide. F18, fibroblasts from an 18-year old donor; F37, fibroblasts from a 37-year old donor; K26, keratinocytes from a 26-year old donor; K37, keratinocytes from a 37-year old donor. Scale bar: $200 \mu \mathrm{m}$. 
Table 1. Colony-forming efficiency assay. Ampho, amphotropic; Baev, baboon endogenous virus; CFE, colony-forming efficiency; Galv, gibbon ape leukaemia virus; GFP, green fluorescent protein; RD114, feline endogenous retrovirus; $n=3$ (sample size); $N=1$ (cell population size).

\begin{tabular}{|c|c|c|}
\hline & Colony forming efficiency & $\begin{array}{l}\text { Percentage of GFP-positive } \\
\text { holoclones and meroclones }\end{array}$ \\
\hline & Mean (SD) & Mean (SD) \\
\hline Untransduced & $14.63 \%(1.10)$ & - \\
\hline \multicolumn{3}{|l|}{ Untransduced } \\
\hline EF-C & $12.80 \%(3.05)$ & - \\
\hline Polybrene & $12.17 \%(1.34)$ & - \\
\hline \multicolumn{3}{|l|}{ Ampho } \\
\hline EF-C & $5.50 \%(1.30)$ & $10.83 \%(2.83)$ \\
\hline Polybrene & $4.97 \%(0.86)$ & $3.87 \%(2.42)$ \\
\hline \multicolumn{3}{|l|}{ Baev } \\
\hline EF-C & $6.07 \%(0.15)$ & $5.28 \%(1.53)$ \\
\hline Polybrene & $5.97 \%(0.32)$ & $5.07 \%(4.53)$ \\
\hline \multicolumn{3}{|l|}{ Galv } \\
\hline EF-C & $5.57 \%(0.38)$ & $7.99 \%(2.95)$ \\
\hline Polybrene & $6.73 \%(1.00)$ & $3.60 \%(3.26)$ \\
\hline \multicolumn{3}{|l|}{ RD114 } \\
\hline EF-C & $6.60 \%(0.79)$ & $6.74 \%(1.67)$ \\
\hline Polybrene & $8.30 \%(0.30)$ & $1.56 \%(2.71)$ \\
\hline
\end{tabular}

to as "SASS-4" in Larouche et al. (2016). TESs were produced with different combinations of transduced cells at MOI of 0.36 and untransduced fibroblasts and keratinocytes. Briefly, 12,000 fibroblasts $/ \mathrm{cm}^{2}$ at $\mathrm{P5}$, transduced or not, were cultured for $26 \mathrm{~d}$ in a fibroblast medium supplemented with $50 \mu \mathrm{g} / \mathrm{mL}$ ascorbic acid (Sigma-Aldrich), until the production of a fibroblast-derived tissue sheet. P2 keratinocytes, transduced or not, were seeded at a density of 200,000 cells $/ \mathrm{cm}^{2}$ on one of the two fibroblastderived tissue sheets and submerged for $4 \mathrm{~d}$ in the keratinocyte medium supplemented with $50 \mu \mathrm{g} / \mathrm{mL}$ ascorbic acid. Then, keratinocytes/fibroblasts sheets were superimposed over a fibroblast-derived tissue sheet to produce the TES. TESs were cultured for $21 \mathrm{~d}$ at an air-liquid interface in keratinocyte medium containing $50 \mu \mathrm{g} / \mathrm{mL}$ ascorbic acid and without epidermal growth factor.

\section{Fluorescence-activated cell sorting,} immunofluorescence and histologic analysis GFP expression in transduced cultured cells was assessed by FACS analysis. HT-1080 cells, fibroblasts and keratinocytes were trypsinised $72 \mathrm{~h}$ after infection and analysed for GFP expression. Fluorescence was measured with a Coulter EPICS XL-MCL flow cytometer and Expo32 software (Beckman Coulter, Brea, CA, USA) or with a FACSCalibur ${ }^{\mathrm{TM}}$ (Becton Dickinson, San Jose, CA, USA).

HA-COLVII expression in transduced cells and in retrovirus-producer cells was assessed by immunofluorescence. HT-1080 cells, 293Vec-AmphoHA-COL7A1 cells, keratinocytes and fibroblasts were cultured in 6-well plates until they reached sub-confluence. Cells were fixed with methanol
(ThermoFisher Scientific, Waltham, MA, USA) or $2 \%$ paraformaldehyde followed by $0.2 \%$ Triton X-100 (BioRad, Mississauga, ON, Canada). Next, cells were incubated with a primary mouse monoclonal antibody raised against HA (1 : 500, clone HA.11; Biolegend, San Diego, CA, USA) followed by an Alexa488-conjugated goat anti-mouse ( $1: 1000$; ThermoFisher Scientific); nuclei were coloured with Hoechst reagent 33258 (Sigma-Aldrich). The number of transduced cells expressing the HA tag was scored by image analysis of at least 20 randomly selected fields. The number of HA-positive cells was divided by the number of cell nuclei.

For immunofluorescence analyses, biopsies from TESs were embedded in Tissue-Tek OCT Compound (Somagen, Edmonton, AB, Canada) and frozen in liquid nitrogen. Immunofluorescence assays for transgene expression and markers were performed on $5 \mathrm{~mm}$-thick cryosections, permeabilised with cold acetone, using the following antibodies: mouse monoclonal anti-HA (1:500; clone HA.11, Biolegend), rabbit polyclonal anti-human collagen IV (1:400; Abcam, Cambridge, MA, USA), mouse monoclonal anti-K10 (1:200; clone RKSE60; Cedarlane, Burlington, ON, Canada), rabbit polyclonal anti-K14 (1:600; Cedarlane), mouse anti-human Ki67 (1 : 800; Becton Dickinson, Franklin Lakes, NJ, USA), rabbit antihuman loricrin (1:240; Covance, Dedham, MA, USA) and mouse anti-human K19 clone A53-B/A244 [1 : 200; gift from U. Karsten, Institute of Biological Sciences, University of Rostock, Germany (Kasper et al., 1987)]. The following secondary antibodies were used: Alexa-488-conjugated goat anti-mouse $(1: 1000)$ and Alexa-594-conjugated goat anti-rabbit $(1: 500)$ (ThermoFisher Scientific). 
For histological analyses, biopsies from TESs were fixed in Histochoice (Amresco, Solon, OH, USA) and embedded in paraffin. $5 \mathrm{~mm}$-thick microtome sections were stained with haematoxylin and eosin.

\section{Results}

Efficient transduction of human fibroblasts and keratinocytes with vectors produced from $293 \mathrm{Vec}$ packaging cell lines in presence of the EF-C peptide Retroviral vectors pseudotyped with the RD114 and Galv envelopes are highly efficient to transduce cells from haematopoietic origin (Ghani et al., 2009; Kelly et al., 2000; Kiem et al., 1997). Our first objective was to discriminate which envelope among Ampho, Baev, Galv and RD114 was the most efficient for the transduction of human fibroblasts and keratinocytes. In addition, the efficiency of polybrene and the EF-C peptide to enhance transduction was compared. GFP was used as a reporter gene to evaluate the retroviral-mediated gene transfer efficacy. Fibroblasts and keratinocytes, extracted from two different healthy donors, were tested. For the two fibroblast populations transduced in the presence of polybrene, the average percentage of GFP-positive fibroblasts was $10.1 \%$ with the Ampho vector and $7.9 \%, 6.4 \%$ and $6.1 \%$ with the Baev, Galv and RD114 viruses, respectively (Fig. 1a). In the presence of the EF-C peptide, $32.3 \%$ of fibroblasts were transduced with the Ampho vector as compared to $25.3 \%, 22.3 \%$ and $23.4 \%$ with the Baev, Galv and RD114 viruses, respectively (Fig. 1a). A similar trend was observed for the two tested keratinocyte populations: the Ampho pseudotyped vector was slightly more efficient than the other vectors. In presence of polybrene, the average percentage of GFP-positive keratinocytes was $44.6 \%$ with the Ampho vector as compared to $32.6 \%, 40.9 \%$ and $42.5 \%$ with the Baev,

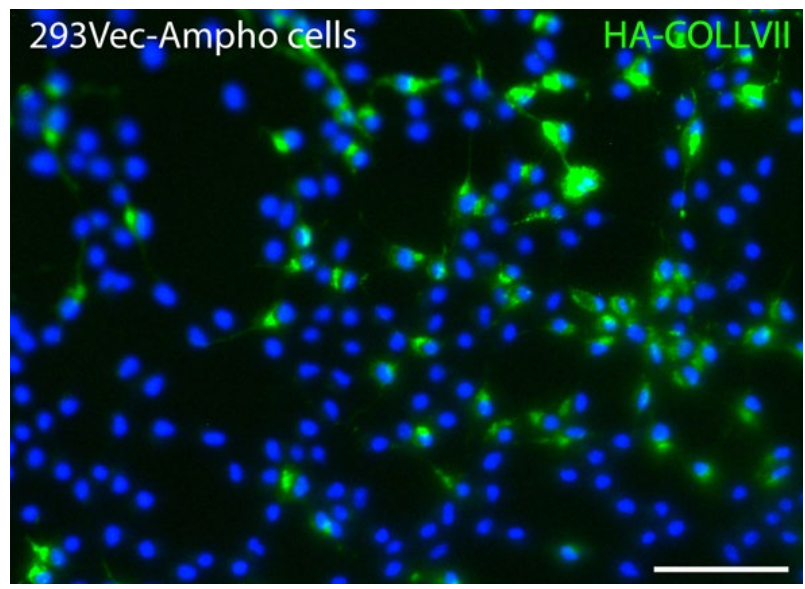

Fig. 2. Representative picture of $293 \mathrm{Vec}-\mathrm{Ampho}$ cells transduced with the $H A-C O L 7 A 1$ vector immunolabeled with anti-HA antibody (green). Hoechst staining of cell nuclei in blue. HA, haemagglutinin tag. Scale bar: $100 \mu \mathrm{m}$.
Galv and RD114 vectors, respectively. In presence of the EF-C peptide, $58.4 \%$ of keratinocytes were GFPpositive with the Ampho vector, compared to $47.5 \%$, $54.8 \%$ and $55.9 \%$ with the Baev, Galv and RD114 vectors, respectively (Fig. 1a). Next, the effect of the transduction enhancers and vectors on clonogenic behaviour of keratinocytes was evaluated. The percentage of colonies formed is indicated in Table 1 and it was in line with previous studies (Barrandon and Green, 1987; Lavoie et al., 2013; Rheinwald and Green, 1975). The transduction enhancers did not appear to affect the CFE. However, regardless of the vector used, a decrease in CFE was observed for transduced, compared with untransduced, keratinocytes (Table 1). The different vectors used did not appear to affect the proportion of GFP-expressing colonies of transduced keratinocytes (Table 1). Also, the morphology of GFP-expressing colonies was evaluated. Typically, keratinocyte stem cells form large colonies, mainly composed of small cells called holoclones (Barrandon and Green, 1987). For each vector, some GFP-expressing holoclones were observed (Fig. 1b), indicating that the transduction protocol allowed for the preservation of keratinocyte stem cells.

Considering that for both keratinocytes and fibroblasts, the vector produced from the Ampho packaging cell line was the most efficient to transfer the GFP gene, while maintaining a normal cellular morphology, experiments were pursued using this packaging cell line. Also, in human fibroblasts and keratinocytes, the EF-C peptide outperformed polybrene as a transduction enhancer of the retroviral-mediated gene transfer.

Efficient retroviral delivery of the COL7A1 gene to human fibroblasts and keratinocytes in the presence of EF-C

The next step was to produce fibroblast and keratinocyte populations that stably expressed an exogenous form of COLVII. The COL7A1 cDNA, delivered by the vector, was linked to a HA tag to allow the discrimination between the endogenous COLVII present in healthy donor cells and the protein expressed by the transgene. To generate stable retrovirus-producer cells, 293Vec-Ampho cells were infected with a $H A-C O L 7 A 1$ virus. Then, cells were cultured until they reached confluence, when the viral supernatant was harvested. $19 \%$ of these cells were HA-positive [standard deviation $(\mathrm{SD})=4$, $n=34$ (sample size), $N=1$ (cell population size)] (Fig. 2). Subsequently, fibroblasts and keratinocytes were infected and the expression of the transgene was assessed by immunofluorescence (Fig. 3). As observed by flow cytometry for the GFP expression, the percentage of transduction of both fibroblasts and keratinocytes was higher when EF-C was used, compared with polybrene. Indeed, $19 \%$ of fibroblasts were transduced $(\mathrm{SD}=5, n=19, N=1)$ in the presence of EF-C and only $4 \%$ with polybrene $(S D=2$, 

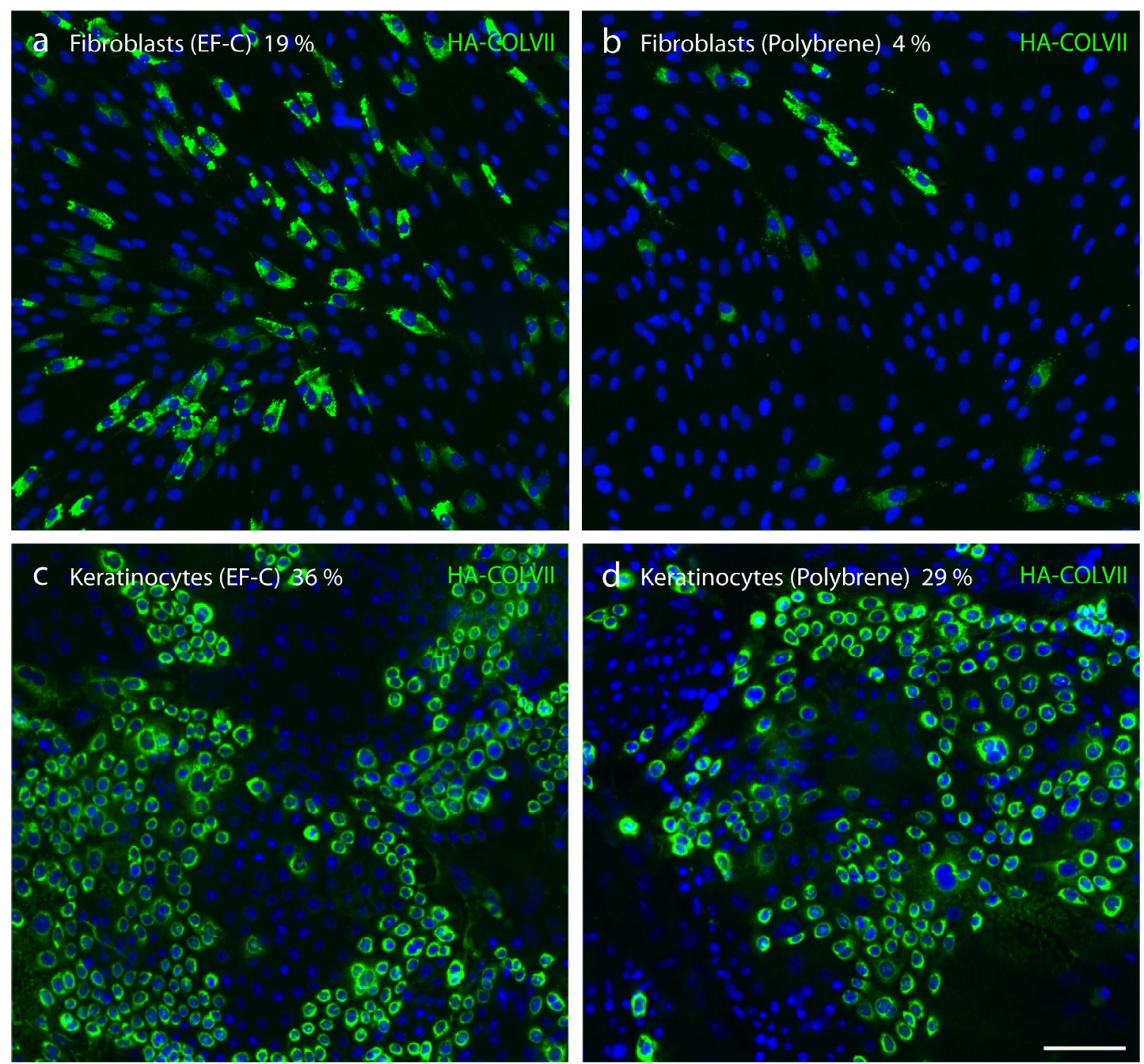

Fig. 3. Expression of HA-COLVII in monocultured transduced cells. Wild-type fibroblasts transduced with the HA-COL7A1 vector produced from the 293Vec-Ampho cells in the presence of (a) EF-C or (b) polybrene. Wild-type keratinocytes transduced with the HA-COL7A1 vector produced from the 293VecAmpho cells in the presence of (c) EF-C or (d) polybrene. Immunolabelling with anti-HA antibody in green. Hoechst staining of cell nuclei in blue. Scale bar: $100 \mu \mathrm{m}$.

$n=20, N=1)$. The difference was less striking with keratinocytes: $36 \%(\mathrm{SD}=6, n=20, N=1)$ of cells were infected in the presence of EF-C compared to $29 \%$ ( $\mathrm{SD}=4, n=20, N=1$ ) with polybrene. These results indicated that the viral delivery of the COL7A1 gene to human fibroblasts and keratinocytes was higher when EF-C was used.

Transduced fibroblasts and keratinocytes in tissueengineered skin substitutes expressed exogenous COLVII

TESs were produced with untransduced cells or cells transduced in the presence of either EF-C or polybrene. Then, different cell combinations were tested: transduced fibroblasts and transduced keratinocytes $(\mathrm{F}+/ \mathrm{K}+\mathrm{TES})$; transduced fibroblasts and untransduced keratinocytes (F+/K- TES); untransduced fibroblasts and transduced keratinocyte (F-/K+ TES) and control untransduced fibroblasts and untransduced keratinocytes (F-/K- TES). HA-
COLVII was detected at the DEJ in $\mathrm{F}+/ \mathrm{K}+\mathrm{TESs}, \mathrm{F}+$ / $\mathrm{K}-\mathrm{TESs}$ and F-/K+ TESs (Fig. 4) and it colocalised with collagen IV, an extracellular matrix protein that is normally present at the DEJ. A continuous intense deposit of HA-COLVII was observed in the $\mathrm{F}+\mathrm{K}+\mathrm{TESs}$ transduced in the presence of the EF-C peptide (Fig. 4a). The staining was continuous, but less intense in $\mathrm{F}+/ \mathrm{K}-\mathrm{TES}$ (Fig. $4 \mathbf{b}$ ) or $\mathrm{F}-/ \mathrm{K}+\mathrm{TESs}$ (Fig. 4c). When the transductions were made in the presence of polybrene, the HA-COLVII staining at the DEJ of $\mathrm{F}+/ \mathrm{K}+$ TESs, $\mathrm{F}+/ \mathrm{K}-$ TESs and $\mathrm{F}-/ \mathrm{K}+\mathrm{TES}$ was discontinued and less intense in comparison with their counterparts transduced in the presence of the EF-C peptide (Fig. 4d-f). The expression of HA-COLVII was also detected in the cytoplasm of keratinocytes in all epidermal layers, as previously observed by others and explainable by the ubiquitous expression of the viral promoter LTR (Gache et al., 2004; Siprashvili et al., 2010). HA-COLVII was undetected in control F-/K- TESs (Fig. 4g). 

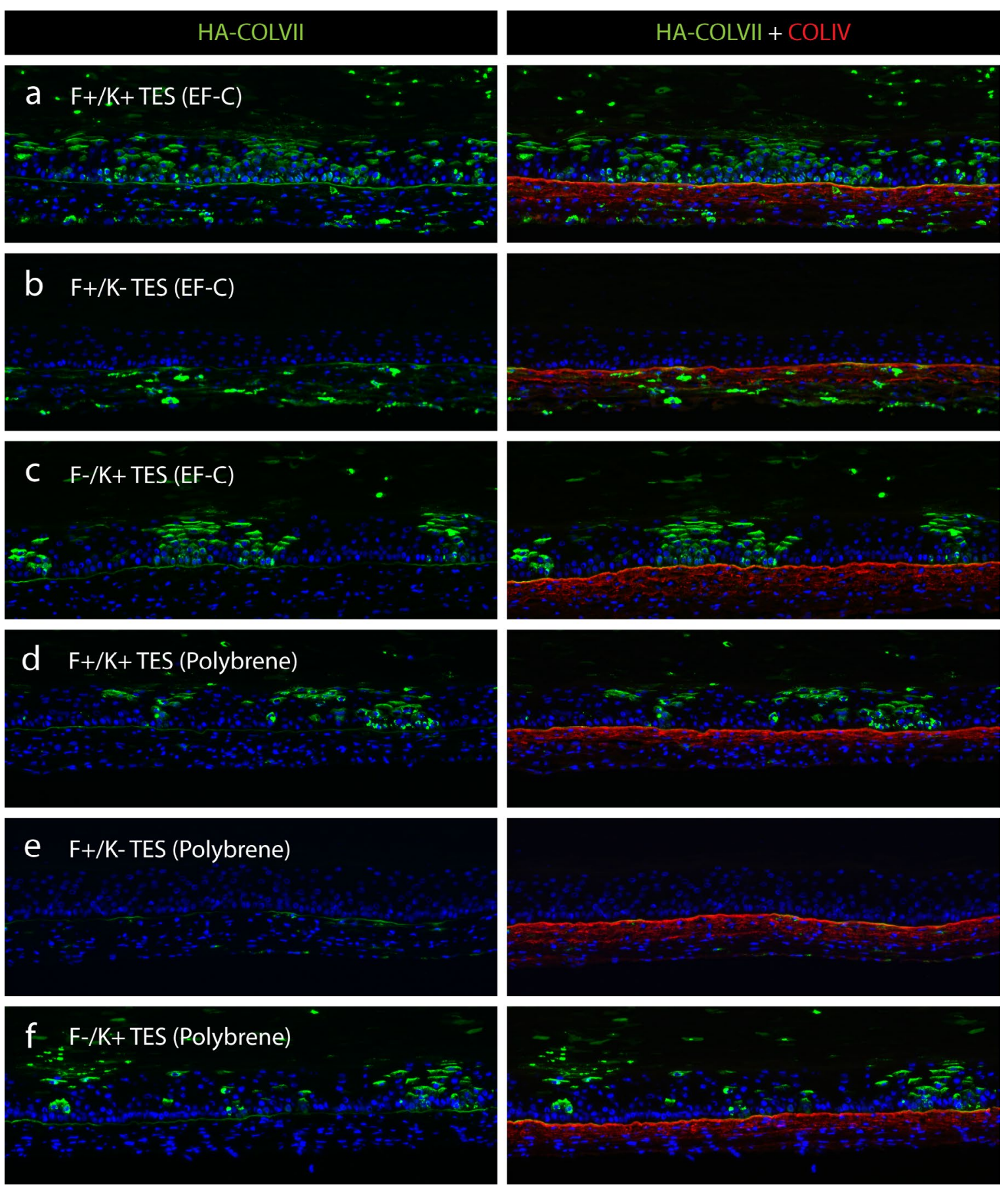

9 F-/K-TES

Fig. 4. Production of HA-COLVII in tissue-engineered skin substitutes cultured in the air-liquid interface for $21 \mathrm{~d}$. Detection of HA-COLVII (left and right columns, green) and type IV collagen (right column, red) by immunofluorescence staining. (a,d) F+/K+ TESs, (b,e) F+/K- TESs, (c,f) F-/K+ TESs and (g) controls $\mathrm{F}-/ \mathrm{K}-\mathrm{TESs}$. Cells were transduced in the presence of (a-c) EF-C and (d-f) polybrene. Hoechst staining of cell nuclei in blue. F- and $\mathrm{K}$ - indicate untransduced fibroblasts and keratinocytes, respectively. F-/ $\mathrm{K}$ - indicates control tissue-engineered skin made from untransduced fibroblasts and untransduced keratinocytes. $\mathrm{F}+$ and $\mathrm{K}+$ indicate transduced fibroblasts and keratinocytes, respectively. F+/K+ TES, F-/ $\mathrm{K}+\mathrm{TES}, \mathrm{F}+\mathrm{K}-\mathrm{TES}$, indicate the 3 types of tissue-engineered skin made from transduced fibroblasts and/ or transduced keratinocytes. COLIV, type IV collagen; HA-COLVII, haemagglutinin-tagged type VII collagen. Scale bar: $100 \mu \mathrm{m}$. 
Transduced keratinocyte stem cells were preserved in tissue-engineered skin substitutes

Long-term expression of a transgene in keratinocytes is only possible if stem cells are transduced. For this reason, the concomitant expression of HACOLVII with keratin 19 (K19), which is expressed by keratinocyte stem cells (Lavoie et al., 2013; Michel et al., 1996; Pontiggia et al., 2009), was investigated. With both transduction enhancers, HA-COLVII expression was detected in K19-positive basal keratinocytes of the TES epidermis (Fig. 5). This result suggested that the transduction protocol used allowed for the transduction of keratinocyte stem cells.

The epidermal proliferation and differentiation profiles were conserved in tissue-engineered skin substitutes made of transduced cells

Normal proliferation and differentiation of the TES epidermis are required for the maintenance of the skin homeostasis. The expression of proliferation and epidermal differentiation markers was assessed by immunofluorescence assays and the results showed a similar expression pattern in TESs produced with transduced cells $(\mathrm{F}+\mathrm{K}+\mathrm{TESs}, \mathrm{F}+\mathrm{K}-\mathrm{TESs}$ and $\mathrm{F}-/$ $\mathrm{K}+$ TESs) as compared with control F-/K- TESs produced with untransduced cells (Fig. 6). The basal keratinocytes expressed keratin 14 (K14) and the proliferation marker Ki67 was detected in the nucleus of many cells within the basal layer. Keratinocytes in suprabasal layers expressed the differentiation marker keratin 10 (K10), whereas loricrin, a granularlayer marker, was present in higher suprabasal layers (Fig. 6a-f).

Haematoxylin and eosin histological analyses of TESs produced with transduced or untransduced cells revealed well-organised skin-like tissues (Fig. $6 \mathrm{~g}-\mathbf{i})$. These results indicated that the transduction process did not alter the histological integrity of TESs.

\section{Discussion}

In this study, an efficient method for retroviral gene transfer into human fibroblasts and keratinocytes using the EF-C peptide was described. Also, TESs produced from transduced fibroblasts and
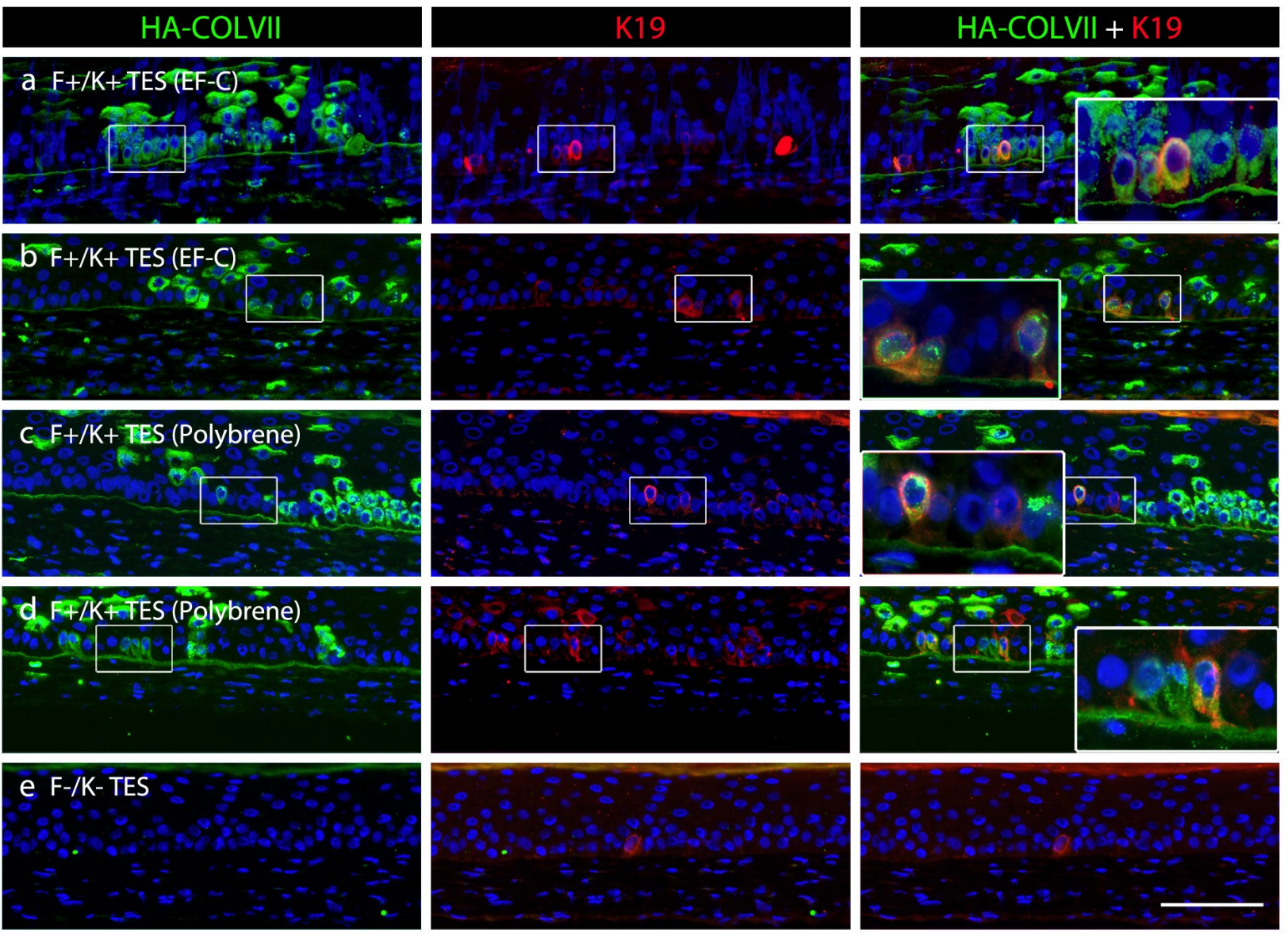

Fig. 5. Co-detection of HA-COLVII and K19 in tissue-engineered skin substitutes cultured $21 \mathrm{~d}$ at the air-liquid interface. F+/K+ TESs transduced in the presence of (a,b) EF-C and (c-d) polybrene. (e) Control F-/K- TES. Immunolabelling of HA-COLVII with anti-HA antibody (green) and anti-K19 (red) is shown in single labelling (left and centre columns) and double (right column). An enlargement of the boxed areas with double positive cells is shown as inserts in the right column. Hoechst staining of cell nuclei in blue. Control F-/K-TESs, tissue-engineered skin made from untransduced fibroblasts and untransduced keratinocytes; F+/K+ TES, tissue-engineered skin made from transduced fibroblasts and transduced keratinocytes. Scale bar: $100 \mathrm{~mm}$. 
keratinocytes expressing the COLVII protein, resulting from the inserted gene, were generated. HA-COLVII expression in K19-positive basal keratinocytes and the presence of transduced holoclones suggested that keratinocyte stem cells were successfully transduced, allowing for the expression of the inserted gene over time. A continuous deposit of the exogenous COLVII was present at the DEJ of TESs, with the best results obtained with cells transduced in presence of the EF-C peptide.

The low transduction efficiency of the target cells is a limiting factor for gene therapy applications that can be improved by different means. In the case of retroviral gene delivery, new versions of stable retrovirus packaging cell lines have been developed. These cells are safer and release recombinant retroviruses with higher titers compared with former versions (Cosset et al., 1995; Sheridan et al., 2000). The GFP viruses used in this study were produced with a set of 293-based retrovirus packaging cell lines, allowing for the production of vectors with titers above $10^{7} \mathrm{ivp} / \mathrm{mL}$ (Ghani et al., 2007; Ghani et al., 2009). The transduction ability of GFP vectors pseudotyped with the Ampho, Baev, Galv and RD114 envelopes was assessed. It was found that the Ampho envelope was more efficient to transduce GFP into fibroblasts than Baev, Galv and RD114.

The long size of the COL7A1 cDNA hinders the generation of high-titer vectors (Goto et al., 2006; Siprashvili et al., 2010; Titeux et al., 2010). In our study, the titer obtained with the $H A-C O L 7 A 1$ vector from the $293 \mathrm{Vec}-$ Ampho population was $2 \times 10^{5} \mathrm{ivp} / \mathrm{mL}$. As only $19 \%$ of the $293 \mathrm{Vec}$ cells were HA-COL7A1positive (Fig. 2), selection of isolated retrovirusproducer clones could be expected to result in titers higher than $10^{6} \mathrm{ivp} / \mathrm{mL}$. However, a retrovirusproducer clone was intentionally not selected, as the HA-COL7A1 vector was not planned to be used for clinical applications. Retrovirus-producer clones, with a codon-optimised version of the COL7A1 cDNA in a self-inactivated (SIN) retroviral backbone, are currently under development in our laboratory and by others using our 293Vec cells (Hennig et al., 2014). Codon optimisation is used to enhance the stability of the transcript, aiming at obtaining high viral titers and transgene expression in transduced cells
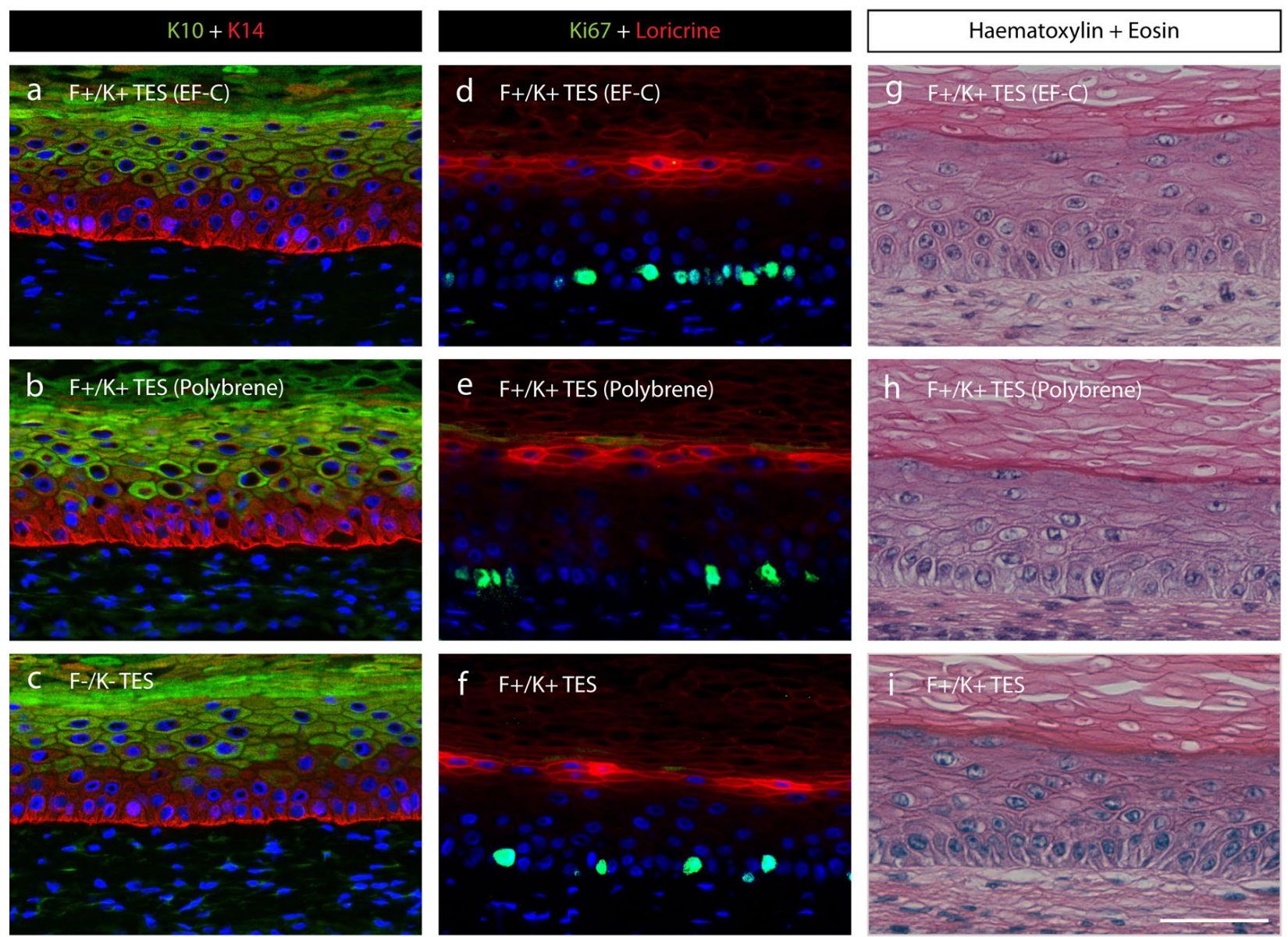

Fig. 6. Differentiation profile of tissue-engineered skin substitutes cultured $21 \mathrm{~d}$ at the air-liquid interface. (a-c) Double immunodetection of K10 (green) and K14 (red). (d-f) Double immunodetection of the proliferation marker Ki67 (green) and the late differentiation marker loricrin (red). Hoechst staining of cell nuclei in blue. (g,i) Histological analysis of TESs. F+/K+ TES transduced in the presence of (a,d,g) EF-C and $(\mathbf{b}, \mathbf{e}, \mathbf{h})$ polybrene; $(\mathbf{c}, \mathbf{f}, \mathbf{i})$ control F-/K- TES. F-/K- TESs, tissue-engineered skin made from untransduced fibroblasts and untransduced keratinocytes; $\mathrm{F}+\mathrm{K}+\mathrm{TES}$, tissue-engineered skin made from transduced fibroblasts and transduced keratinocytes; K10, keratin 10; K14, keratin 14. Scale bar: $100 \mu \mathrm{m}$. 
(Moreno-Carranza et al., 2009). Also, SIN retroviral vectors without viral enhancers are safer and less prone to transformation upon integration when compared to vectors with intact LTRs (Cavazza et al., 2013; Hacein-Bey-Abina et al., 2008; Howe et al., 2008; Modlich et al., 2006). Fibronectin and retronectin enhance retroviral gene transfer in keratinocytes (Bajaj et al., 2005; Goto et al., 2006), but the cost of the good manufacturing practices (GMP)grade fibronectin or retronectin and the numerous manipulation steps limit the clinical development of a gene therapy strategy for RDEB. One alternative could be the use of a molecule easier to manipulate than retronectin or fibronectin that could be added simultaneously with the vector, without further manipulations. The EF-C peptide could be such a molecule as it has the ability to self-assemble into nanofibrils and to increase retroviral transduction of peripheral blood lymphocytes, macrophages and haematopoietic stem cells (Yolamanova et al., 2013). In the current study, it was found that, in fibroblasts, EF-C increased the gene transfer of GFP and $H A$ COL7A1 vectors by 3.1-fold and 4.5-fold, respectively (Fig. 1a), when compared to polybrene (Fig. 3c,d). A 1.3-fold increase in keratinocyte transduction was obtained with EF-C, but, as the infection values were high and not in the linear range, the difference was likely more than 2-fold.

A sustained expression of COLVII in grafted skin for the whole patient's life is desirable for an effective gene therapy treatment of RDEB. A recent paper from De Luca's group shows that the grafting of transfected holoclones over $80 \%$ of total body surface area results in long-term correction in a patient suffering from JEB (Hirsch et al., 2017). As described in our study for RDEB cells (Fig. 4), and by others (Georgiadis et al., 2016; Goto et al., 2006; Jackow et al., 2016; Titeux et al., 2010), transduced fibroblasts produced COLVII that relocated at the DEJ. However, the long-term persistence of these cells in our TESs remains to be proven. As shown previously, keratinocyte stem cells persist in the TES produced by the self-assembly approach and are suitable for the permanent closure of full-thickness skin injuries in human patients (Duranceau et al., 2014). In the present study, transgene expression was observed in holoclones, which are associated to stem cells (Barrandon and Green, 1987). Moreover, the transgene expression persisted in the keratinocytes after several cell divisions occurring during the $28 \mathrm{~d}$ necessary between transfection and TES fixation. The presence of double positive keratinocytes for K19 and the transgene in the basal layer of the TES epidermis indicated that the in vitro model was adequate. The long-term stable expression of the transduced gene in TES in vivo remains to be confirmed after grafting in an animal model.

Siprashvili et al. (2016), in a gene therapy study with four RDEB patients treated with gene-corrected epidermal sheet grafts, report that COLVII expression detected at the DEJ is associated with healing improvement, but the response is variable and declines over time (Siprashvili et al., 2016). A failure to target keratinocyte stem cells, an induction of their differentiation during the gene-transfer procedure or a variable engraftment can explain these results. In this trial, the transduction efficiencies are in the range of $50-70 \%$ with a spinoculation protocol (Siprashvili et al., 2016). This percentage might have been insufficient to target stem cells and the harsh infection condition could have led to cellular differentiation. In comparison, more than $90 \%$ of keratinocytes are transduced in the JEB studies with a gentle transduction procedure (De Rosa et al., 2014; Hirsch et al., 2017; Mavilio et al., 2006). This important difference in viral transduction is due to the extended length of the COL7A1 cDNA that prevents the generation of high-titer vector batches. The $3.5 \mathrm{kbp} L A M B 3 \mathrm{cDNA}$ used in the JEB studies leads to high-titer retroviral vector production.

In conclusion, our results showed that our optimised method to transfer gene in fibroblasts and keratinocytes allowed for the production of TESs that expressed and organised COLVII at the DEJ. Thus, it is believed that it is worth continuing the work on a TES genetically modified to correct RDEB, in order to develop a permanent local treatment for patients suffering from this disease.

\section{Acknowledgments}

Conflicts of interest: KG and MC are inventors on a patent (US2009098648) that has been licensed to BioVec Pharma. KG and MC own equity in BioVec Pharma.

All authors have made substantial contributions. Authors' contributions are as follow: ADP, DL, KG, FB, $M C$ and $L G$ conceived and designed the experiments. ADP, KG and FB performed the experiments and collected the data. ADP, DL, LG, SCG, SL, VJM and MC analysed the data. VJM, MC and LG provided reagents/materials/analysis tools. ADP, DL and MC wrote the paper. All authors revised the manuscript and approved the final version to be published. LG and $\mathrm{MC}$ are co-senior authors and acquired funding to perform the study.

This work was supported by the Réseau de thérapie cellulaire et tissulaire (ThéCell), Fondation du Grand Défi Pierre Lavoie (FGDPL) and the Canadian Institutes of Health Research (CIHR) grants MOP-133639 (MC) and FDN-143213 (LG). LG is the holder of the Canadian Research Chair on Stem Cell and Tissue Engineering. ADP received scholarships from FDGPL, CHU de Québec - Université Laval Research Centre. The funders had no role in study design, data collection and analysis, decision to publish or preparation of the manuscript.

The authors would like to thank Israël Martel, Amélie Lavoie, Amélie Morissette, Benjamin Goyer, 
Carolyne Bisson-Simard, Laurence Cantin-Warren and Rina Guignard for their technical assistance. The authors are grateful to Bartha M. Knoppers, who contributed with her expertise on the ethical aspects of the project regarding genomics and biotechnology.

\section{References}

Aumailley M, Has C, Tunggal L, BrucknerTuderman L (2006) Molecular basis of inherited skinblistering disorders, and therapeutic implications. Expert Rev Mol Med 8: 1-21.

Bajaj BG, Lei P, Andreadis ST (2005) Efficient gene transfer to human epidermal keratinocytes on fibronectin: in vitro evidence for transduction of epidermal stem cells. Mol Ther 11: 969-979.

Barrandon Y, Green H (1987) Three clonal types of keratinocyte with different capacities for multiplication. Proc Natl Acad Sci U S A 84: 23022306.

Bauer JW, Koller J, Murauer EM, De Rosa L, Enzo E, Carulli S, Bondanza S, Recchia A, Muss W, Diem A, Mayr E, Schlager P, Gratz IK, Pellegrini G, De Luca M (2016) Closure of a large chronic wound through transplantation of gene-corrected epidermal stem cells. J Invest Dermatol 137: 778-781.

Bell E, Ivarsson B, Merrill C (1979) Production of a tissue-like structure by contraction of collagen lattices by human fibroblasts of different proliferative potential in vitro. Proc Natl Acad Sci U S A 76: 12741278.

Berthod F, Hayek D, Damour O, Collombel C (1993) Collagen synthesis by fibroblasts cultured within a collagen sponge. Biomaterials 14: 749-754.

Bisson F, Rochefort E, Lavoie A, Larouche D, Zaniolo K, Simard-Bisson C, Damour O, Auger FA, Guerin SL, Germain L (2013) Irradiated human dermal fibroblasts are as efficient as mouse fibroblasts as a feeder layer to improve human epidermal cell culture lifespan. Int J Mol Sci 14: 4684-4704.

Boyce ST, Kagan RJ, Greenhalgh DG, Warner P, Yakuboff KP, Palmieri T, Warden GD (2006) Cultured skin substitutes reduce requirements for harvesting of skin autograft for closure of excised, full-thickness burns. J Trauma 60: 821-829.

Bruckner-Tuderman L, Hopfner B, HammamiHauasli N (1999) Biology of anchoring fibrils: lessons from dystrophic epidermolysis bullosa. Matrix Biol 18: 43-54.

Cavazza A, Cocchiarella F, Bartholomae C, Schmidt M, Pincelli C, Larcher F, Mavilio F (2013) Self-inactivating MLV vectors have a reduced genotoxic profile in human epidermal keratinocytes. Gene Ther 20: 949-957.

Chen M, Kasahara N, Keene DR, Chan L, Hoeffler WK, Finlay D, Barcova M, Cannon PM, Mazurek C, Woodley DT (2002) Restoration of type VII collagen expression and function in dystrophic epidermolysis bullosa. Nat Genet 32: 670-675.
Cosset FL, Takeuchi Y, Battini JL, Weiss RA, Collins MK (1995) High-titer packaging cells producing recombinant retroviruses resistant to human serum. J Virol 69: 7430-7436.

De Rosa L, Carulli S, Cocchiarella F, Quaglino D, Enzo E, Franchini E, Giannetti A, De Santis G, Recchia A, Pellegrini G, De Luca M (2014) Long-term stability and safety of transgenic cultured epidermal stem cells in gene therapy of junctional epidermolysis bullosa. Stem Cell Reports 2: 1-8.

Duranceau L GH, Bortoluzzi P, Moulin V, Auger FA, Germain L (2014) Successful grafting of novel autologous tissue-engineered skin substitutes (dermis and epidermis) on twelve burn patients. J Burn Care Res 35: S121.

Fine JD, Bruckner-Tuderman L, Eady RA, Bauer EA, Bauer JW, Has C, Heagerty A, Hintner H, Hovnanian A, Jonkman MF, Leigh I, Marinkovich MP, Martinez AE, McGrath JA, Mellerio JE, Moss C, Murrell DF, Shimizu H, Uitto J, Woodley D, Zambruno G (2014) Inherited epidermolysis bullosa: updated recommendations on diagnosis and classification. J Am Acad Dermatol 70: 1103-1126.

Gache Y, Baldeschi C, Del Rio M, GagnouxPalacios L, Larcher F, Lacour JP, Meneguzzi G (2004) Construction of skin equivalents for gene therapy of recessive dystrophic epidermolysis bullosa. Hum Gene Ther 15: 921-933.

Georgiadis C, Syed F, Petrova A, Abdul-Wahab A, Lwin SM, Farzaneh F, Chan L, Ghani S, Fleck RA, Glover L, McMillan JR, Chen M, Thrasher AJ, McGrath JA, Di WL, Qasim W (2016) Lentiviral engineered fibroblasts expressing codon-optimized COL7A1 restore anchoring fibrils in RDEB. J Invest Dermatol 136: 284-292.

Germain L, Rouabhia M, Guignard R, Carrier L, Bouvard V, Auger FA (1993) Improvement of human keratinocyte isolation and culture using thermolysin. Burns 19: 99-104.

Ghani K, Cottin S, Kamen A, Caruso M (2007) Generation of a high-titer packaging cell line for the production of retroviral vectors in suspension and serum-free media. Gene Ther 14: 1705-1711.

Ghani K, Wang X, de Campos-Lima PO, Olszewska M, Kamen A, Riviere I, Caruso M (2009) Efficient human hematopoietic cell transduction using RD114and GALV-pseudotyped retroviral vectors produced in suspension and serum-free media. Hum Gene Ther 20: $966-974$.

Goto M, Sawamura D, Ito K, Abe M, Nishie W, Sakai K, Shibaki A, Akiyama M, Shimizu H (2006) Fibroblasts show more potential as target cells than keratinocytes in COL7A1 gene therapy of dystrophic epidermolysis bullosa. J Invest Dermatol 126: 766-772.

Hacein-Bey-Abina S, Garrigue A, Wang GP, Soulier J, Lim A, Morillon E, Clappier E, Caccavelli L, Delabesse E, Beldjord K, Asnafi V, MacIntyre E, Dal Cortivo L, Radford I, Brousse N, Sigaux F, Moshous D, Hauer J, Borkhardt A, Belohradsky $\mathrm{BH}$, Wintergerst U, Velez MC, Leiva L, Sorensen R, Wulffraat N, Blanche S, Bushman FD, Fischer A, 
Cavazzana-Calvo M (2008) Insertional oncogenesis in 4 patients after retrovirus-mediated gene therapy of SCID-X1. J Clin Invest 118: 3132-3142.

Hennig K, Raasch L, Kolbe C, Weidner S, Leisegang M, Uckert W, Titeux M, Hovnanian A, Kuehlcke K, Loew R (2014) HEK293-based production platform for gamma-retroviral (self-inactivating) vectors: application for safe and efficient transfer of COL7A1 cDNA. Hum Gene Ther Clin Dev 25: 218-228.

Hirsch T, Rothoeft T, Teig N, Bauer JW, Pellegrini G, De Rosa L, Scaglione D, Reichelt J, Klausegger A, Kneisz D, Romano O, Secone Seconetti A, Contin R, Enzo E, Jurman I, Carulli S, Jacobsen F, Luecke T, Lehnhardt M, Fischer M, Kueckelhaus M, Quaglino D, Morgante M, Bicciato S, Bondanza S, De Luca M (2017) Regeneration of the entire human epidermis using transgenic stem cells. Nature 551: 327-332.

Howe SJ, Mansour MR, Schwarzwaelder K, Bartholomae C, Hubank M, Kempski H, Brugman $\mathrm{MH}$, Pike-Overzet K, Chatters SJ, de Ridder D, Gilmour KC, Adams S, Thornhill SI, Parsley KL, Staal FJ, Gale RE, Linch DC, Bayford J, Brown L, Quaye M, Kinnon C, Ancliff P, Webb DK, Schmidt M, von Kalle C, Gaspar HB, Thrasher AJ (2008) Insertional mutagenesis combined with acquired somatic mutations causes leukemogenesis following gene therapy of SCID-X1 patients. J Clin Invest 118: 3143-3150.

Jackow J, Titeux M, Portier S, Charbonnier S, Ganier C, Gaucher S, Hovnanian A (2016) Gene-Corrected Fibroblast Therapy for Recessive Dystrophic Epidermolysis Bullosa using a SelfInactivating COL7A1 Retroviral Vector. J Invest Dermatol 136: 1346-1354.

Kasper M, Stosiek P, Typlt H, Karsten U (1987) Histological evaluation of three new monoclonal anti-cytokeratin antibodies. 1. Normal tissues. Eur J Cancer Clin Oncol 23: 137-147.

Kelly PF, Vandergriff J, Nathwani A, Nienhuis AW, Vanin EF (2000) Highly efficient gene transfer into cord blood nonobese diabetic/severe combined immunodeficiency repopulating cells by oncoretroviral vector particles pseudotyped with the feline endogenous retrovirus (RD114) envelope protein. Blood 96: 1206-1214.

Kern JS, Gruninger G, Imsak R, Muller ML, Schumann H, Kiritsi D, Emmert S, Borozdin W, Kohlhase J, Bruckner-Tuderman L, Has C (2009) Forty-two novel COL7A1 mutations and the role of a frequent single nucleotide polymorphism in the MMP1 promoter in modulation of disease severity in a large European dystrophic epidermolysis bullosa cohort. Br J Dermatol 161: 1089-1097.

Kiem HP, Heyward S, Winkler A, Potter J, Allen JM, Miller AD, Andrews RG (1997) Gene transfer into marrow repopulating cells: comparison between amphotropic and gibbon ape leukemia virus pseudotyped retroviral vectors in a competitive repopulation assay in baboons. Blood 90: 4638-4645.

Larouche D, Cantin-Warren L, Desgagne M, Guignard R, Martel I, Ayoub A, Lavoie A, Gauvin
R, Auger FA, Moulin VJ, Germain L (2016) Improved methods to produce tissue-engineered skin substitutes suitable for the permanent closure of full-thickness skin injuries. Biores Open Access 5: 320-329.

Lavoie A, Fugere C, Beauparlant A, Goyer B, Larouche D, Paquet C, Desgagne M, Sauve S, Robitaille H, Dunnwald M, Kim DH, Pouliot R, Fradette J, Germain L (2013) Human epithelial stem cells persist within tissue-engineered skin produced by the self-assembly approach. Tissue Eng Part A 19: 1023-1038.

Mavilio F, Pellegrini G, Ferrari S, Di Nunzio F, Di Iorio E, Recchia A, Maruggi G, Ferrari G, Provasi E, Bonini C, Capurro S, Conti A, Magnoni C, Giannetti A, De Luca M (2006) Correction of junctional epidermolysis bullosa by transplantation of genetically modified epidermal stem cells. Nat Med 12: 1397-1402.

Meier C, Weil T, Kirchhoff F, Munch J (2014) Peptide nanofibrils as enhancers of retroviral gene transfer. Wiley Interdiscip Rev Nanomed Nanobiotechnol 6: 438-451.

Michel M, Torok N, Godbout MJ, Lussier M, Gaudreau P, Royal A, Germain L (1996) Keratin 19 as a biochemical marker of skin stem cells in vivo and in vitro: keratin 19 expressing cells are differentially localized in function of anatomic sites, and their number varies with donor age and culture stage. J Cell Sci 109: 1017-1028.

Modlich U, Bohne J, Schmidt M, von Kalle C, Knoss S, Schambach A, Baum C (2006) Cell-culture assays reveal the importance of retroviral vector design for insertional genotoxicity. Blood 108: 25452553.

Moreno-Carranza B, Gentsch M, Stein S, Schambach A, Santilli G, Rudolf E, Ryser MF, Haria S, Thrasher AJ, Baum C, Brenner S, Grez M (2009) Transgene optimization significantly improves SIN vector titers, gp91phox expression and reconstitution of superoxide production in X-CGD cells. Gene Ther 16: 111-118.

Pontiggia L, Biedermann T, Meuli M, Widmer D, Bottcher-Haberzeth S, Schiestl C, Schneider J, Braziulis E, Montano I, Meuli-Simmen C, Reichmann E (2009) Markers to evaluate the quality and selfrenewing potential of engineered human skin substitutes in vitro and after transplantation. J Invest Dermatol 129: 480-490.

Pouliot R, Larouche D, Auger FA, Juhasz J, Xu W, Li H, Germain L (2002) Reconstructed human skin produced in vitro and grafted on athymic mice. Transplantation 73: 1751-1757.

Qiao J, Roy V, Girard MH, Caruso M (2002) High translation efficiency is mediated by the encephalomyocarditis virus internal ribosomal entry sites if the natural sequence surrounding the eleventh AUG is retained. Hum Gene Ther 13: 881-887.

Rashidghamat E, McGrath JA (2017) Novel and emerging therapies in the treatment of recessive dystrophic epidermolysis bullosa. Intractable Rare Dis Res 6: 6-20. 
Rheinwald J, Green H (1975) Serial cultivation of strains of human epidermal keratinocytes: the formation of keratinizing colonies from single cells. Cell 6: 331-344.

Sheridan PL, Bodner M, Lynn A, Phuong TK, DePolo NJ, de la Vega DJ, Jr., O’Dea J, Nguyen K, McCormack JE, Driver DA, Townsend K, Ibanez CE, Sajjadi NC, Greengard JS, Moore MD, Respess J, Chang SM, Dubensky TW, Jr., Jolly DJ, Sauter SL (2000) Generation of retroviral packaging and producer cell lines for large-scale vector production and clinical application: improved safety and high titer. Mol Ther 2: 262-275.

Siprashvili Z, Nguyen NT, Bezchinsky MY, Marinkovich MP, Lane AT, Khavari PA (2010) Long-term type VII collagen restoration to human epidermolysis bullosa skin tissue. Hum Gene Ther 21: 1299-1310.

Siprashvili Z, Nguyen NT, Gorell ES, Loutit K, Khuu P, Furukawa LK, Lorenz HP, Leung TH, Keene DR, Rieger KE, Khavari P, Lane AT, Tang JY, Marinkovich MP (2016) Safety and wound outcomes following genetically corrected autologous epidermal grafts inpatients with recessive dystrophic epidermolysis bullosa. JAMA 316: 1808-1817.

Sun BK, Siprashvili Z, Khavari PA (2014) Advances in skin grafting and treatment of cutaneous wounds. Science 346: 941-945.

Titeux M, Pendaries V, Zanta-Boussif MA, Decha A, Pironon N, Tonasso L, Mejia JE, Brice A, Danos O,
Hovnanian A (2010) SIN retroviral vectors expressing COL7A1 under human promoters for ex vivo gene therapy of recessive dystrophic epidermolysis bullosa. Mol Ther 18: 1509-1518.

Uitto J, Bruckner-Tuderman L, Christiano AM, McGrath JA, Has C, South AP, Kopelan B, Robinson EC (2016) Progress toward treatment and cure of epidermolysis bullosa: summary of the DEBRA international research symposium EB2015. J Invest Dermatol 136: 352-358.

Yolamanova M, Meier C, Shaytan AK, Vas V, Bertoncini CW, Arnold F, Zirafi O, Usmani SM, Muller JA, Sauter D, Goffinet C, Palesch D, Walther P, Roan NR, Geiger H, Lunov O, Simmet T, Bohne J, Schrezenmeier H, Schwarz K, Standker L, Forssmann WG, Salvatella X, Khalatur PG, Khokhlov AR, Knowles TP, Weil T, Kirchhoff F, Munch J (2013) Peptide nanofibrils boost retroviral gene transfer and provide a rapid means for concentrating viruses. Nat Nanotechnol 8: 130-136.

Editor's notes: All of the matters raised by the reviewers have been incorporated in the main text, so there is no Discussion with reviewers section for this paper.

The Scientific Editor responsible for this paper was Mauro Alini. 